\title{
Assessment of knowledge related to diabetes mellitus among patients attending a dental college in Salem city-A cross sectional study
}

Avaliação do conhecimento relacionado ao diabetes mellitus entre pacientes atendidos em uma faculdade de odontologia na cidade de Salem: um estudo transversal.

N SARAVANAN $^{1}, S_{\text {VENKATALAKSHMI }}{ }^{1}$, C BHARATH ${ }^{1}$

1 - Dept of Public Health Dentistry - VMSDC - Salem - Tamil nadu - India.

\section{ABSTRACT}

Objective: Diabetes mellitus is a metabolic disorder characterized by chronic hyperglycemia with a global prevalence rate of $8.3 \%$. Diabetes not only affect general health but also oral health leading to periodontitis. Low level of knowledge about diabetes and lack of awareness regarding preventive options will ultimately impact self-care behavior. To assess diabetes related knowledge among patients attending Vinayaka Mission's Sankarachariyar (VMS) Dental College outpatient department in Salem city, Tamilnadu. Materials And Methods: A cross sectional study was carried out for about two weeks which encompassed a convenient sample of 400 subjects aged 18-80 years. Knowledge of respondents regarding diabetes was measured using 15 item self-administered modified Diabetes Knowledge Questionnaire (DKQ). Results: When knowledge regarding cause of diabetes was considered, only $40 \%$ of subjects were aware that diabetes is not a communicable disease. Almost half (57.5\%) of the participants believed that sweet consumption causes diabetes. Furthermore, 55\% participants knew that diabetes can damage kidney and around $54.5 \%$ agreed that diabetes can also affect dental health. The higher mean knowledge scores was observed among males compared to females and the difference was statistically insignicant $(p=0.37)$. Significantly higher mean knowledge scores were dissipated by subjects with graduation education $(p=0.01)$, those with professional occupation $(\mathrm{p}=0.02)$ and participant from urban location $(p=0.00)$. Conclusion: The study showed significantly lower level of awareness regarding diabetes among rural respondents compared to

\section{RESUMO}

Objetivo: Diabetes mellitus é uma doença metabólica caracterizada por hiperglicemia crônica com taxa de prevalência global de 8,3\%. O diabetes não só afeta a saúde geral, mas também a saúde bucal que leva à periodontite. O baixo nível de conhecimento sobre diabetes e a falta de conhecimento sobre as opções preventivas afetarão o comportamento de autocuidado. o objetivo deste estudo foi avaliar o conhecimento relacionado à diabetes entre os pacientes atendidos no ambulatório de Odontologia de Vinayaka Mission's Sankarachariyar, na cidade de Salem, Tamilnadu. Material e Métodos: um estudo transversal foi realizado por cerca de duas semanas, que abrangeu uma amostra conveniente de 400 indivíduos entre 18 e 80 anos. O conhecimento dos entrevistados em relação ao diabetes foi medido usando 15 itens de Questionário de Conhecimento de Diabetes (DCD) auto-administrado. Resultados: Quando o conhecimento sobre a causa de diabetes foi considerado, apenas $40 \%$ dos indivíduos estavam cientes de que o diabetes não é uma doença transmissível. Quase metade (57,5\%) dos participantes acreditava que o consumo de doce causa diabetes. Além disso, $55 \%$ dos participantes sabiam que a diabetes pode danificar os rins e cerca de $54,5 \%$ concordaram que o diabetes também pode afetar a saúde dentária. A maior pontuação média do conhecimento foi observada entre os homens em comparação com as mulheres e a diferença não foi estatisticamente significante $(\mathrm{p}=$ $0,37)$. As pontuações médias significativamente mais altas foram distribuídas nos indivíduos com educação de graduação $(\mathrm{p}=0,01)$, aqueles com ocupação profissional $(\mathrm{p}=0,02)$ e participantes de localização urbana $(p=0,00)$. Conclusão: o estudo mostrou níveis significativamente mais baixos de conscientização em relação ao diabetes entre os entrevistados rurais em 
urban residents. Gap related to diabetes mellitus knowledge should be abridged between rural and urban province in order to reduce disease burden and to yield positive health outcomes in the society.

\section{KEYWORDS}

Diabetes mellitus; Diabetes management; Knowledge; Oral self-care. comparação com os residentes urbanos. A lacuna relacionada ao conhecimento de diabetes mellitus deve ser suprida entre a província rural e urbana, a fim de reduzir a carga de doenças e produzir resultados positivos para a saúde na sociedade.

\section{PALAVRAS-CHAVE}

Diabetes mellitus; Gerenciamento do diabetes; Conhecimento; Autocuidado oral.

\section{INTRODUCTION}

$\mathrm{D}$ iabetes mellitus (DM) is a metabolic disorder characterized by chronic hyperglycemia with a global prevalence rate of $8.3 \%$ [1]. Worldwide the number of people with diabetes has considerably increased between 1980 and 2014 rising from 108 million to 422 million $[2,3]$. Furthermore, India already had 62 million people with diabetes and estimated prevalence rate by 2030 is 79.4 million [4]. Apart from genetic factors, the incidence rate is raising due to change in dietary habits \& lifestyle patterns which could ultimately impact quality of life. Moreover, Diabetes is eight leading cause of deaths among both the sexes and accounts for about 1.5 million diabetes deaths and 2.2million deaths from associated complications worldwide in 2012 [5]. Several studies [6-11] reported that diabetes contributes to development of various microvascular and macrovascular complications in turn decreasing life expectancy by about 10-30\%. Diabetes not only affect general health but also oral health. Epidemiological studies [12-15] revealed that uncontrolled diabetes can affect the salivary glands resulting in xerostomia, sialosis, taste impairment and increases the risk for dental caries. Furthermore, impaired leukocyte function and reduced cellular immunity in diabetes patients enhance susceptibility to periodontal diseases. Additionally inadequately controlled moderate to severe periodontitis increase gram negative bacterial load which eventually triggers insulin resistance through C-Reactive Proteins (CRP). Thus adversely affect glycemic control $[16,17]$. Henceforth diabetes and periodontal disease shows bidirectional relationship. In view of this, World Health Organization (WHO) theme for the World Health Day in 2016 is "Halt the raise, Beat diabetes".

Considerable body of evidence reveal that more than $80 \%$ of people with diabetes live in low and middle income countries [18,19]. Report of World Bank in 2005 [20] stated $41.6 \%$ of total Indian population falls below international poverty line of US\$ 1.25 a day, reflecting poor affordability by $50 \%$ of Indians towards health related issues. Additionally Low level of knowledge about diabetes and lack of awareness regarding preventive options will ultimately impact self-care behavior and poor utilization of facilities available. Thus Knowledge forms a basis for the adoption of good health related practices. Various studies [21-23] conducted worldwide had shown, people lack knowledge allied to diabetes etiology, prevention and associated complications in turn leading to poor levels of self-care.

As DM is a preventable disease, raising public awareness plays a vital role in diabetes management and reducing economic burden especially in developing countries like India, which spend only 3\% Gross Domestic Product (GDP) on health \& family welfare development. In the light of these findings, it is important to assess knowledge regarding diabetes for planning preventive programs in order to favorably influence both oral and general 
health. Hence the aim of this study is to assess diabetes related knowledge among patients attending Vinayaka Mission's Sankarachariyar (VMS) Dental College outpatient department in Salem, Tamilnadu, India.

\section{MATERIAL AND METHODS}

A cross sectional questionnaire based study was carried out to assess knowledge related to diabetes among the patients attending VMS Dental College out-patient department, Salem, Tamilnadu. Ethical clearance was obtained from the Institutional Research Committee VMSDC/ PHD/0022/2016. The study was conducted in the month of November 2016 for about two weeks which encompassed a convenient sample of 400 subjects aged 18-80 years. Informed consent was obtained from the participants and those willing to participate were included in the study. Exclusion criteria include participants of less than 18 years old, critically ill patients and subjects with lack of intellectual function. The proforma was designed to collect the information which comprised of two sections. The first section gathered demographic details (age, gender, education, occupation, income and location) from the participants. In the second section, knowledge of respondents regarding diabetes was measured using 15 item self-administered modified Diabetes Knowledge Questionnaire (DKQ) which was developed based on 24-item diabetes knowledge questionnaire developed by the Starr Country Texas, Diabetes Education Study [24]. The responses were re $\neg$ corded on a three point likert scale. Each "Yes" response was scored ' 2 ', ' 1 ' for "No" response and '0' for "Don't Know". The questionnaire assesses knowledge regarding cause of diabetes, symptoms, associated complications and on prevention of diabetes. The questionnaire was developed both in English and Tamil language (local language). Validity and reliability of the questionnaire was assessed before the start of the study, which showed good test and retest reliability of 0.7. A pilot study was conducted among a group of 40 subjects to check whether the questionnaire was easily understood and certain modifications were done accordingly. The questionnaire was distributed to the subjects and only completed forms were included in the analysis. In case of illiterate subjects, surveyors were trained and practiced how to interview subjects to complete the structured questionnaire. Those who scored at or above 16 point were considered as having good knowledge whereas those who scored below 15 point have poor knowledge regarding diabetes mellitus. The data was analyzed using Statistical Package for Social Sciences (SPSS) package version 20.0. Chi square test was used to associate the knowledge scores of the study population with variables. Student t-test and ANOVA were used to compare mean knowledge scores with variables. $\mathrm{p}<0.05$ was considered statistically significant.

\section{RESULTS}

Out of 400 participants, 216 (54\%) were males and 184 (46\%) were females with a mean age of $39.1 \pm 3.09$ years. Majority of the study participants belonged to Urban $(65.2 \%)$ followed by Rural (34.8\%) with the age ranged from 18-80 years and utmost number of respondents were in 20-30 years of age group. When education was considered, around $16.6 \%$ were graduates, $55.6 \%$ possessed high school education, $13.8 \%$ completed primary education and $14 \%$ were illiterate. Majority of the study respondents were students \& professional (57.7\%) followed by farmer (15.8\%) and business people (12.5\%) respectively. Most of them belong to average income group (42.3\%).

When knowledge regarding cause of diabetes was considered, only $40 \%$ of subjects were aware that diabetes is not a communicable disease. Around $57.3 \%$ and $56.1 \%$ of the participants were cognizant that it is a hereditary disease and caused by insulin hormone deficiency respectively. About $57.5 \%$ of the participants believed that sweet consumption causes diabetes. Similarly with respect to complications, $68 \%$ respondents were aware that there will be delayed wound healing for diabetic patients. Furthermore, 55\% participants knew that diabetes can damage 
kidney and around 54.5\% agreed that diabetes can also affect dental health. Knowledge based on prevention revealed, $67.8 \%$ perceived that regular exercise can prevent diabetes and $83.3 \%$ assumed that diabetes can be controlled by adopting healthy life styles [Table I].

Comparison of the correct knowledge responses based on gender, revealed that males had a better knowledge compared to females and significant difference was noted only for question $2(\mathrm{P}<0.03)$. When education was considered, participants with high school education followed by graduates had good knowledge compared to subjects with primary school education. However, a significant difference was observed for questions $1(\mathrm{p}<0.006), 2(\mathrm{p}<0.003)$ and $4(\mathrm{p}<0.02)$. Furthermore, professionals and students were better knowledgeable compared to other categories of occupation with a significant difference noted for questions 1 and $11(\mathrm{p}<0.03)$. Based on location, Urban population had more knowledge compared to rural respondents regarding diabetes with significant $(\mathrm{p}<0.05)$ difference for questions 1,4,6,11,13 and 14 [Table II, III].
Table II - Comparison of study subjects based on knowledge scores according to variables

\begin{tabular}{lccc|}
\hline $\begin{array}{l}\text { Variable } \\
\text { GENDER }\end{array}$ & Poor knowledge (n) & Good knowledge (n) & p value \\
\hline Male & 36 & 180 & 0.068 \\
\hline Female & 49 & 135 & \\
\hline EDUCATION & & & \\
\hline Illiterate & 8 & 46 & 0.193 \\
\hline P r i m a r y & 3 & 56 & \\
school & 8 & 179 & \\
\hline High school & 4 & 96 & \\
\hline Graduation & & & \\
\hline OCCUPATION & 26 & 10 & $0.010^{*}$ \\
\hline Laborers & 3 & 41 & \\
\hline Farmer & 8 & 30 & \\
\hline House wife & 4 & 59 & $0.000^{*}$ \\
\hline Business & 5 & 214 & \\
\hline Students and & 7 & 121 & \\
\hline Professional & 17 & 255 & \\
\hline LOCATION & & & \\
\hline Rural & & & \\
\hline Urban & & & \\
\hline
\end{tabular}

${ }^{*}$ Satistically significant $(p<0.05)$

Table I - Participants response rate to diabetes knowledge questionnaire

\begin{tabular}{|llccc|}
\hline S.NO & QUESTIONS & Yesn(\%) & Non(\%) & Don't know n(\%) \\
\hline 1 & Are you a known diabetic? & $90(22.5)$ & $300(75)$ & $10(2.5)$ \\
\hline 2 & Diabetes can occur in 30 years of life & $277(69.3)$ & $85(21.3)$ & $38(9.5)$ \\
\hline $3^{*}$ & Diabetes is a communicable disease & $124(31)$ & $160(40)$ & $116(29)$ \\
\hline 4 & Diabetes is a hereditary disease & $229(57.3)$ & $90(22.5)$ & $81(20.3)$ \\
\hline $5^{\star}$ & Consumption of sweets cause diabetes & $230(57.5)$ & $110(27.5)$ & $60(15)$ \\
\hline 6 & Diabetes caused by insulin hormone deficiency & $224(56.1)$ & $81(20.3)$ & $95(23.8)$ \\
\hline 7 & Frequent urination and thirst are the symptoms of diabetes & $275(68.8)$ & $69(17.3)$ & $56(14.1)$ \\
\hline 8 & Regular exercise can prevent diabetes & $271(67.8)$ & $68(17)$ & $61(15.3)$ \\
\hline 9 & Monthly once examination of blood glucose level is mandatory & $272(68)$ & $72(18)$ & $56(14)$ \\
\hline 10 & Wound healing will be slow for diabetic patients & $272(68)$ & $75(18.8)$ & $53(13.3)$ \\
\hline 11 & Diabetes can damage kidneys & $220(55)$ & $79(19.8)$ & $101(25.3)$ \\
\hline 12 & Diabetes can affect the dental health & $218(54.5)$ & $86(21.5)$ & $96(24)$ \\
\hline $13^{*}$ & Diabetes patient should always take insulin injection & $176(44)$ & $120(30)$ & $104(26)$ \\
\hline $14^{*}$ & Diabetes is a curable disease & $238(59.5)$ & $106(26.5)$ & $56(14)$ \\
\hline 15 & Diabetes can be controlled by adopting healthy life style & $333(83.3)$ & $38(9.5)$ & $29(7.3)$ \\
\hline
\end{tabular}

*The correct response for these questions is "No", for all other questions the correct response is "Yes" 
Table III - Questions asked for the assessment of knowledge responses among the study population stratified based on gender, education, occupation and location

\begin{tabular}{|c|c|c|c|c|c|}
\hline \multirow[t]{2}{*}{ S.NO } & \multirow[t]{2}{*}{ QUESTIONS } & \multicolumn{4}{|l|}{ p value } \\
\hline & & Gender & Education & Occupation & Location \\
\hline 1 & Are you a known diabetic? & 0.063 & $0.006^{\star}$ & $0.034^{*}$ & $0.025^{\star}$ \\
\hline 2 & Diabetes can occur in 30 years of life & $0.032^{*}$ & $0.003^{*}$ & 0.100 & 0.518 \\
\hline 3 & Diabetes is a communicable disease & 0.748 & 0.164 & 0.059 & 0.609 \\
\hline 4 & Diabetes is a hereditary disease & 0.111 & $0.021^{\star}$ & 0.235 & $0.031^{\star}$ \\
\hline 5 & Consumption of Sweets causes diabetes & 0.604 & 0.794 & 0.151 & 0.785 \\
\hline 6 & Diabetes caused by insulin hormone deficiency & 0.702 & 0.069 & 0.195 & $0.037^{\star}$ \\
\hline 7 & Frequent urination and thirst are the symptoms of diabetes & 0.287 & 0.475 & 0.294 & 0.107 \\
\hline 8 & Regular exercise can prevent diabetes & 0.775 & 0.210 & 0.869 & 0.781 \\
\hline 9 & Monthly once examination of blood glucose level is mandatory & 0.161 & 0.294 & 0.603 & 0.309 \\
\hline 10 & Wound healing will be slow for diabetic patients & 0.774 & 0.664 & 0.319 & 0.183 \\
\hline 11 & Diabetes can damage kidneys & 0.151 & 0.223 & $0.036^{\star}$ & $0.005^{\star}$ \\
\hline 12 & Diabetes can affect the dental health & 0.867 & 0.902 & 0.884 & 0.939 \\
\hline 13 & Diabetes patient should always take insulin injection & 0.079 & 0.518 & 0.748 & $0.000^{\star}$ \\
\hline 14 & Diabetes is a curable disease & 0.052 & 0.694 & 0.318 & $0.047^{\star}$ \\
\hline 15 & Diabetes can be controlled by adopting healthy life style & 0.776 & 0.345 & 0.835 & 0.162 \\
\hline
\end{tabular}

${ }^{*}$ statistically significant at $p<0.05$.

The higher mean knowledge scores was observed among males compared to females and the difference was statistically insignicant $\quad(\mathrm{p}=0.37)$. Significantly higher mean knowledge scores were dissipated by subjects with graduation education $(\mathrm{p}=0.01)$, those with professional occupation $(\mathrm{p}=0.02)$ and participants from urban location $(\mathrm{p}=0.00)$ [Table IV].

\section{DISCUSSION}

Health is a most common concern in most communities and in the last few decades considerable body of evidence accrued indicating association between health and life style of individuals. As diabetes remains to be a widespread problem all over the world, emphasis has been shifted from prevention of disease to promotion of healthy life styles. Moreover, raising the level of knowledge regarding diabetes will ultimately reduce risk of illness. In the present study, overall good knowledge regarding diabetes was observed among the participants
Table IV - Comparison of Mean $\pm S D$ scores of knowledge based on variables

\begin{tabular}{|c|c|c|}
\hline Variables & $\begin{array}{l}\text { Knowledge } \\
\text { (Mean } \pm S D \text { ) }\end{array}$ & p value \\
\hline \multicolumn{2}{|l|}{ GENDER } & \multirow{3}{*}{0.374} \\
\hline Males & $21.50 \pm 3.59$ & \\
\hline Females & $20.77 \pm 4.15$ & \\
\hline \multicolumn{2}{|l|}{ EDUCATION } & \multirow{5}{*}{$0.015^{\star}$} \\
\hline Illiterate & $19.66 \pm 4.69$ & \\
\hline Primary & $20.80 \pm 3.54$ & \\
\hline High school & $20.93 \pm 3.76$ & \\
\hline Graduation & $21.68 \pm 4.14$ & \\
\hline \multicolumn{2}{|l|}{ OCCUPATION } & \multirow{6}{*}{$0.026^{\star}$} \\
\hline Laborer & $19.66 \pm 4.63$ & \\
\hline Farmer & $21.17 \pm 2.75$ & \\
\hline House wife & $20.61 \pm 3.74$ & \\
\hline Business & $21.49 \pm 4.25$ & \\
\hline Students and Professional & $23.04 \pm 3.01$ & \\
\hline \multicolumn{2}{|l|}{ LOCATION } & \multirow{3}{*}{$0.000^{\star}$} \\
\hline Rural & $20.17 \pm 4.25$ & \\
\hline Urban & $21.01 \pm 3.64$ & \\
\hline
\end{tabular}

*Satistically significant $(p<0.05), S D=S t a n d a r d$ deviation 
that constitute considerable proportion of sample and was in agreement with the studies done by Padma K et al. [25] and Parera DP et al. [26]. As majority of the study respondents were students, it might have contributed to the high knowledge scores. Furthermore, location of two medical and three dental colleges within the Salem town might also lead to increased awareness about diabetes. In contrast, studies done by Shrestha N et al. [27], Upadhyay DK et al. [28], Binh TQ et al. [29] and Hawal NP et al [30] reported poor diabetes knowledge scores.

In the existing study though good number of respondents had adequate knowledge scores, yet higher percentage (60\%) of study subjects has misconception that diabetes is a communicable disease. This finding indicates it's time to enact towards this misconception.

On the other hand, contradictory finding was observed in a study by Thungathurthi $\mathrm{S}$ et al. [22] where only $10.3 \%$ reported diabetes as communicable disease.

More than half of the study subjects were well acquainted that diabetes is due to lack of insulin hormone production and is a hereditary disease. Similar findings were observed in a study by Shrestha N et al. [27]. Only $50 \%$ of the participants were well aware of diabetes complications which is comparatively less to studies done by Thungathurthi S et al, 66\% [22] and Muninarayana C et al., 74\% [31]. About $54.5 \%$ were aware that diabetes affect dental health which is comparable to the studies done by Ullah $\mathrm{F}$ et al. [11] and Eldarrat $\mathrm{AH}$ [12]. But this percentage is quite less indicating the need to educate masses about bidirectional relationship between oral health and diabetes.

In current study around two third of respondents were aware of importance of regular exercise and adopting healthy life styles in preventing diabetes. This finding was in consistent with observations done by Shah VN et al. [32], Padma K et al. [25] and Wynn Nyunt $S$ et al. [33]. Whereas in Binn TQ et al. study [29] majority of the participants (60\%) disagreed with this statement.
When rural and urban variance in knowledge towards diabetes was considered, study revealed that rural dwellers had poor knowledge which was in accordance with Bihn TQ et al. [29] and Deepa M et al. [34]. This provincial differences in knowledge scores could be attributed to differences in educational levels. Though males had high mean knowledge scores compared to females, this difference was not statistically significant which was comparable to the observations found by Shrestha N et al. [27] and Saleh F et al. [35]. Contradictory findings were found in studies done by Rhee MK et al. [36], Santos PF, et al. [37], Thungathurthi S et al. [22].

Better mean knowledge scores was observed among subject with higher occupation status and education level, reflecting educated person may be more inquisitive and could gather more information through greater contact with education materials as reported in Shrestha $\mathrm{N}$ et al. [27] study.

\section{CONCLUSION}

The study showed significantly lower level of awareness regarding diabetes among rural respondents compared to urban residents. In country like India with conventional medical practices and lack of equitable distribution of health care, gap related to diabetes mellitus knowledge should be abridged between rural and urban province in order to reduce disease burden and to yield positive health outcomes in the society. The findings of the study emphasis the necessity of providing comprehensive diabetes education through awareness programs for the masses about misconceptions, potential effect of oral alterations on diabetes control and diabetes complications. The current study necessitates need for adoption of Beveridge model in order to achieve the goal "equity in health".

\section{LIMITATIONS}

However, we acknowledge that the study had certain limitations such as small sample size and was carried out in a hospital setting at a 
single center, so the results has to be generalized with caution. Moreover, findings are based on self -reported data from participants which limits validity of the data and necessitate to correlate with the objective oral and general health measures.

\section{REFERENCES}

1. Berhe KK, Gebru HB, Kahsay HB, Kahsay AA. Assessment of diabetes knowledge and its associated factors among type 2 diabetes patients in Mekelle and Ayder referral hospital, Ethiopia. J Diabetes Metab 2014;5(5):378-84.

2. World Health Organization: Global status report on noncommunicable diseases 2014. Geneva: WHO; 2015.

3. Wild S, Roglic G, Green A, Sicree R, King H. Global prevalence of diabetes estimates for the year 2000 and projections for 2030. Diabetes Care. 2004 May;27(5):1047-53.

4. Kaveeshwar SA, Cornwall J. The current state of diabetes mellitus in India. Australas Med J. 2014 Jan 31;7(1):45-8. doi: 10.4066/ AMJ.2013.1979. eCollection 2014

5. WHO Mortality Database [online database]. Geneva: World Health Organization;(http://apps.who.int/healthinfo/statistics/mortality/ causeofdeath_query/, accessed 10 August 2017).

6. Bhansali A, Chattopadhyay A, Dash RJ. Mortality in diabetes: a retrospective analysis from a tertiary care hospital in North India. Diabetes Res Clin Pract. 2003 May;60(2):119-24.

7. Mohan V, Shanthirani CS, Deepa M, Deepa R, Unnikrishnan RI, Datta M. Mortality rates due to diabetes in a selected urban south Indian population-the Chennai Urban Population Study. J Assoc Physicians India. 2006 Feb;54:113-7.

8. Tseng $\mathrm{CH}$. Mortality and causes of death in a national sample of diabetes patients in Taiwan. Diabetes Care. 2004 Jul;27(7):1605-9.

9. Morgan CL, Currie CJ, Peter JR. Relationship between diabetes and mortality: a population study using record linkage. Diabetes Care. 2000 Aug;23(8):1103-7.

10. Sasisekhar TVD, Alekhya Y, Jagadeesh CH, Sudha A. Diabetes complications leading to mortality. IJRRMS 2012;2(3):24-7.

11. Ullah F, Afridi AK, Rahim F, Ashfaq M, Khan S, Shabbier G et al. Knowledge of diabetic complications in patients with diabetes mellitus. J Ayub Med Coll Abbottabad. 2015 Apr-Jun;27(2):360-3

12. Eldarrat AH. Awareness and attitude of Diabetic patients about their increased risk for oral diseases. Oral Health Prev Dent. 2011;9(3):235-41.

13. Lalla RV, D’Ambrosio JA. Dental management considerations for the patient with diabetes mellitus. J Am Dent Assoc. 2001 0ct:132(10):1425-32.

14. Manfredi M, McCullough MJ, Vescovi P, Al-kaarawi ZM, Porter SR. Update on diabetes mellitus and related oral diseases. Oral Dis. 2004 Jul;10(4):187-200.

15. Skamagas M, Breen TL, LeRoith D. Update on diabetes mellitus: prevention, treatment and association with oral diseases. Oral Dis. 2008 Mar;14(2):105-14. doi: 10.1111/j.1601-0825.2007.01425.x.
16. Preshaw PM, Alba AL, Herrera D, Jepsen S, Konstantinidis A, Makrilakis K, et al. Periodontitis and diabetes: a two-way relationship. Diabetologia. 2012 Jan;55(1):21-31. doi: 10.1007/ s00125-011-2342-y. Epub 2011 Nov 6.

17. Teeuw WJ, Gerdes VE, Loos BG. Effect of periodontal treatment on glycemic control of diabetes patients. Diabetes Care. 2010 Feb;33(2):421-7. doi: 10.2337/dc09-1378.

18. Fatema K, Hossain S, Natasha K, Chowdhury HK, Alter J, Khan T et al. Knowledge, attitude and practice regarding diabetes mellitus among nondiabetic and diabetic study participants in Bangladesh. BMC Public Health. 2017 Apr 26;17(1):364. doi: 10.1186/s12889-0174285-9.

19. Islam FMA, Chakrabarti R, Dirani M, Islam MT, Ormaby, G et al. Knowledge, attitude and practice of diabetes in rural Bangladesh: The Bangladesh population based diabetes and eye study (BPDES). PLoS One. 2014 0ct 14;9(10):e110368. doi: 10.1371/journal. pone.0110368. eCollection 2014.

20. Reddy KV, Moon NJ, Reddy KE, Chandrakala S. Time to implement national oral health policy in India. Indian J Public Health. 2014 OctDec;58(4):267-9. doi: 10.4103/0019-557X.146290.

21. Joshi SR, Das AK, Vijay VJ, Mohan V. Challenges in diabetes care in India: sheer numbers, lack of awareness and inadequate control. J Assoc Physicians India. 2008 Jun;56:443-50.

22. Thungathurthi S, Thungathurthi S, Vijay Kumar G. Self-care knowledge on diabetes among diabetic patients in Warangal region. Int J Life Sci Pharm Res 2012;2(2):16-21.

23. Gulabani M, John M, Isaac R. Knowledge of diabetes, its treatment and complications among diabetes patients in a tertiary care hospital. Indian J Community Med. 2008 Jul;33(3):204-6. doi: 10.4103/0970-0218.42068.

24. Garcia AA, Villagomez ET, Brown SA, Kouzekanani K, Hanis CL. The Starr Country diabetes education study. Development of the Spanish-language diabetes knowledge questionnaire. Diabetes Care. 2001 Jan;24(1):16-21.

25. Padma K, Bele SD, Boddhare TN, Valsangar S. Evaluation of knowledge and self-care practices in diabetes patients and their role in disease management. National J Community Med. 2012;3(1):3-6.

26. Perera DP, De Silva RE, Perera WLS. Knowledge of diabetes among type 2 diabetes patients attending a primary health care clinic in Sri Lanka. East Mediterr Health J. 2013 Jul;19(7):644-8.

27. Shrestha N, Yadav SB, Joshi AM, Patel BDP, Shrestha J, Bharkher DL. Diabetes knowledge and associated factors among diabetes patients in Central Nepal. Int J Collaborative Res Internal Med Public Health. 2015;7(5):82-91.

28. Upadhyay DK, Palaian S, Shankar PR, Mishra P. Knowledge, attitude and practices about diabetes among diabetes patients in western Nepal. Rawal Med J. 2008;33(1):8-11.

29. Binh TQ, Phuong PT, Nhung BT. Knowledge and associated factors towards type 2 diabetes among a rural population in the red river delat region, Vietnam. Rural Remote Health. 2015 JulSep;15(3):3275. Epub 2015 Sep 26.

30. Hawal NP, Shivaswamy MS, Kambar S, Patil S, Hiremath MB. Knowledge, attitude and behavior regarding self-care practices among type 2 diabetes mellitus patients residing in urban areas of South India. Int Multidisciplinary Res J. 2012;2(12):31-5. 
31. Muninarayana C, Balachandra G, Hiremath SG, Iyengar K, Anil NS. Prevalence and awareness regarding diabetes mellitus in rural Tamaka, kolar. Int J Diabetes Dev Ctries. 2010 Jan;30(1):18-21. doi: 10.4103/0973-3930.60005.

32. Shah VN, Kamdar PK, Shah N. Assessing theknowledge, attitudes and practice of type 2 diabetesamong patients of Saurashtra region, Gujarat. Int J Diabetes Dev Ctries. 2009 Jul;29(3):118-22. doi: 10.4103/0973-3930.54288.

33. Wynn Nyunt S, Howteerakul N, Suwannapong N, Rajatanun T. Selfefficacy, self-care behaviors andglycemic control among type-2 diabetes patientsattending two private clinics in Yangon, Myanmar. Southeast Asian J Trop Med Public Health. 2010 Jul;41(4):943-51.

34. Deepa M, Bhansali A, Anjana RM, Pradeepa R, Joshi SR, Joshi PP, et al. Knowledge and awareness of diabetes in urban and rural India: the Indian Council of Medical Research India Diabetes
Study (Phase I): Indian Council of Medical Research India Diabetes 4. Indian J Endocrinol Metab. 2014 May;18(3):379-85. doi: 10.4103/2230-8210.131191.

35. Saleh F, Mumu SJ, Ara F, Begum HA, Ali L. Knowledge and self-care practices regarding diabetes among newly diagnosed type 2 diabetes in Bangladesh: a crosssectional study. BMC Public Health. 2012;12:1112.

36. Rhee MK, Cook CB, El-kebbi I, Lyles RH, Dunbar VG, Panayioto RM, et al. Barriers to diabetes education in urban patients: perception, patterns and associated factors. Diabetes Educ. 2005 MayJun;31(3):410-7.

37. Lemes Dos Santos, Dos Santos PF, Dos Santos PR, Ferrari GS, Fonseca GA, Ferrari CK. Knowledge of diabetes mellitus: Does gender make a difference? Osong Public Health Res Perspect. 2014 Aug;5(4):199-203. doi: 10.1016/j.phrp.2014.06.004. Epub 2014 Jul 5.

\section{Dr. C. Bharath}

\section{(Corresponding address)}

Senior Lecturer,

Dept of Public Health Dentistry,

VMSDC, Salem, Tamil nadu, India.

E mail id: drbharath6@gmail.com 